\title{
On Perfection of Punitive Damages System in China-from the Perspective of Promoting Social Harmony Governance
}

\author{
Zhi-Wei-Lin XU \\ Department of Law and Political Science, North China Electric Power University, Baoding, China, \\ 071003
}

Keywords: Punitive damages system, Tort relief, Social governance, Law perfection.

\begin{abstract}
Punitive damages system is designed to response to the damages caused by the malicious torts due to the defects of traditional compensatory damages system in the tort relief. Nowadays in China, the social unfairness and disharmony resulted from the lots of torts caused by the advantaged to the disadvantaged call for more applications of the punitive damages system. In practice, the current system of punitive damages system takes on many shortages, such as limited application scope, difficulties in determining the amount of compensation, willfully being infringed etc. Therefore, from the perspective of promoting social harmony governance in China, the measures such as strengthening legislation and relevant judicial interpretation and extending the application scope and so on should be taken to perfect the punitive damages system.
\end{abstract}

\section{Introduction}

With the haste development of market economy in China, the traditional compensatory damages has not fill our daily needs. Many advantaged easily infringe maliciously the rights of disadvantaged. At the same time, during legal action, rigid system of compensatory damages makes victims spend more than the money which victims get because of the his damages, which leads to victims having difficulties in protecting their rights. Nowadays, the punitive damages system supplementing the traditional compensatory damages is used around the world. This kind of system through punishing the wrongdoer safeguards the legitimate interests of the victims and tries to promote social justice. Certainly, the system of punitive damages system have some difficulties during social practice such as the uncertain amount of compensation and knowing fake and buying fake(willfully being infringed), and so on. On the basis of previous studies, this article renders a few suggestions in the hope to the punitive damages system in China.

\section{Definition of punitive damages system and its functions}

The compensatory damages are used only to compensate for the loss which the victim lost. Essentially, it is a kind of transaction and it equal to the same exchange of property damage. To offenders, compensation for damages caused by intentional also acts as a transaction. So compensatory damages is difficult to play the role of sanctions for the wealthy, even make compensation law is controlled by the wealthy. The inherent system of compensatory damages is incapable on fully restoring the rights of victims and warning community, maintaining the value of social equity and justice. To compensate for this lack of law, a system of punitive damages system develops from tort relief. "Oxford Dictionary of Law" delimit punitive damages system as "It is an important way of damages, it is often used to indicate that a court or jury against the defendant intentionally, severe or savage infringement violations negative evaluation. This compensation applies equally to high-pressure public officials, arbitrary behavior, in this case, in accordance with the interests of the defendant's conduct derived from the said defendant obtained, far more than he should have to pay compensation to the plaintiff. In some cases, according to the statute, such compensation can also be used for defamation." Equally, Chinese Professor Wang Liming believe that "Damages refers to the amount of compensation made by the court for compensation in excess of actual damages. It has multiple functions such as compensating the loss suffered by the victim, punishing and constraining illegal behavior. As for punitive damages system function, Taiwan 
scholars Chen Congfu think it has four major functions: the punishment, compensation, containment and private enforcement. Punishment, it punishes the perpetrators of subjective bad faith and maintains social justice, it make the law play a fundamental role which is encouraging good and deterring evil, safeguarding the fundamental interests of the victim. Compensation, asking the amount of compensation from victims in order to restore the rights of the victim which was hurt, so the rights which was infringed can recover as much as possible. What the system of punitive damages system advance is fully considering the cost of the victims spend safeguarding their legitimate interests. Containment, reflecting the social management function of punitive damages system. Simply, it uses exemplary compensation to make the offenders pay more on malicious behavior, so the offenders may weigh the pros and cons to consider whether for their behavior before their bad behavior. Private enforcement, punitive damages system often let the victims get a few times the damaged interests, it stimulates people to protect the interests of their own so that it can safeguard the legitimate rights and interests of themselves better.

\section{The application of the punitive damages system in China and its dilemma}

\section{The application of the punitive damages system in China}

In our country the first rule of punitive damages system is "Law of the People's Republic of China on Protecting Consumers' Rights and Interests" which was implemented on January 1, 1994.The provisions of article 49 of the law is "Business operators found to have committed fraud in providing goods or services shall, as demanded, compensate the consumer with a sum doubling what the consumers have paid for such commodities services." That is the article we usually called "double damages". Its connotation is the same as punitive damages system. In 2003 the Supreme people's court issued "Applicable Law Explanations on Some Issues Relating to Commercial Housing Sale Contract Disputes". The provisions of article 8, 9 and 14 of the law formulate that the buyers in 6 cases can claim for punitive damages in the commercial housing sale contracts. "Food Safety Law of the People's Republic of China" was released in 2009. The provisions of article 96 paragraph 2 of the law formulates: "When any manufacturer produces any food not conforming to the food safety standards or sells any food knowing its nonconformity with the food safety standards, the customer can demand the manufacturer or the seller to pay a penalty 10 times of the paid amount, in addition to the compensation for the loss thereof." "Tort Liabilities Law of the People's Republic of China" which was implemented in 2009 is different with the above several laws. It apply to all product tort field. The provisions of article 47 of the law formulate: "Where a manufacturer or seller knowing any defect of a product continues to manufacture or sell the product and the defect causes a death or any serious damage to the health of another person, the victim shall be entitled to require the corresponding punitive compensation." This is the first time in our country law explicitly mention the concept of punitive damages system, revealing the progress of the system of punitive damages system in China.

\section{The application dilemma of punitive damages system in China}

When we know the benefit of punitive damages system, we should also know that it has difficulties in practice. First, the scope of application of the system of punitive damages system should be enlarged. From legislation, we are easy make out that punitive damages system only is used on product, it is not enough for complex social life. It cannot solve problems such as damages of bodily harm and environmental pollution. And simple compensatory damages cannot contain maliciously infringing tort before the event. Injurers often don't pay extra heavy price because of malicious behavior, victims often cannot have enough compensation money, and the requirement of punishing evil cannot be realized. In fact, it destroys the function of law which can punish evil and protect benevolence. It should harm to realize social justice and fairness. So it is not enough for us to protect our rights. Second, it is difficult to make sure the amount of compensation. As a system of compensation, making sure the amount is the most important point to compensate victims effectively. But there are two problems. The one is the compensation of emotional damage. Because the degree of 
emotional damage has no objective standard, the amount of compensation is hard to make sure. That make the court of law solve this problem difficultly. Also, inflation affect the amount .With the development of society, currency keep devaluing every year. Punitive damages system as a kind of one-time compensation has difficulties in reckoning devaluation in the future. In practice, the amount od compensation is determined by injurer's wealth. This is not fair in law. Responsibility should be determined on offender's behavior and the result. Third, the application of the intentional torts. This point performs especially on knowing fake and buying fake. Building system of punitive damages system essentially assert their legal rights, but at the same time the professional team profit built and make money by doing anti-counterfeiting trade and the team is covered on the "protecting rights". Fourth, some social elements such as the industry of insurance which affects the punishment of functions. Because of the developed industry of insurance ,insurance is always used to pay on damages, the punishment function is transferred and counteract. If the amount of punitive damages system is too large, it will bring defendants ' s overweight economic cost, and that will be transferred on consumers. In addition, this kind of compensation will encourage personal lawsuit, and even make more and more meaningless lawsuit, contouring the original idea of the system.

\section{The suggestions on perfecting the punitive damages system in China}

Firstly, the suggestions of the scope of application. Beside it is used on product, the scope should be enlarged to solve problems about tort. Just like the words professor Wang Liming said: "The responsibility of tort is the same as the responsibility of law. They all have functions to punish and educate people who break the law. The law without punishment has lost original nature of legal responsibility." In our country, we should build system of punitive damages system on the tort field of body and intellectual property rights to protect victims' rights. Secondly, the suggestions on compensation amounts. Punitive damages system is compensate for original compensation damages, the fine is different from compensation amounts. So the amount of fine should take the compensation damages as standard. Also, the law should set the lowest standard of amounts. And we should consider the amount of damages which may be affected by inflation. Meanwhile, we should consider specially about the valuable product(such as property). The suggestions of judicial practice. One we should legislate clearly and set clear-cut judicial review to ensure that laws are observed. The other one needs judges improve fair consciousness and needs injurers and victims improve the consciousness of protecting rights. So the amount can be determined fairly. Thirdly, the suggestions on knowing fake and buying fake. In fact, this problem is caused essentially because the market is not standardized. We should start from the fundament to standardize market and ensure the quality of goods to maintain the legitimate interests of the consumers. Finally, the suggestions on the industry of insurance. Through the legislation or judicial interpretation, we should make the amount of punitive damages system be independent of insurance business to ensure the realization of the purpose of punishment.

\section{Summary}

The punitive damages system is insufficient, but its progressive significance and practicability fully illustrates the necessity of perfecting the system in our country. So we hope that we can safeguard social fairness and justice better through the establishment of the localization of Chinese system of punitive damages system.

\section{References}

[1]David M. Walkker. Oxford Dictionary of Law [M].Li Shuangyuan, etc. Beijing: Law press, 2006:260-270.

[2]Wang Liming. Researches on the Punitive Damages System [M]. Beijing: China social science, 2000 . 
[3]Wang Lifeng. Punitive Damages System [A]\Professor Liang Civil and Commercial Law: Volume 15 [M]. Beijing: Law press, 2000:59.

[4]Chen Congfu. Researches on Tort Liability Principles and Punitive Damages System [M]. Beijing: Peking University press, 2005:217.

[5] Li Shigang. Good at Double-edged Sword: Limits and Allocation of "Punitive Damages" [J]. Journal of Nanyang Normal Institute (social science edition), 2010, 9 (4): 7-8.

[6] Wang Liming. Research imputation principle of tort law [M] Beijing: China University of Politics and Law Press, 1992:54. 